\title{
The Idea of Democracy and the Eighteenth Century
}

Koen Stapelbroek

One of the leading questions of this volume is whether the perceived shift from centralised state politics to more intricate structures of power distribution and its management affects the democratic quality of modern societies. ${ }^{1}$ This question triggers many other questions, first of all concerning ideas of democracy. Yet, proceeding to answer the initial question by attempting to define democracy (or the democratic quality of a society) - thus confronting the issue head on - would be hopelessly naïve.

Throughout history, the notion has had too many contradictory meanings to allow for any definitive qualifications. With there being so little grounds for understanding democracy in an unequivocal sense, it is remarkable that the term "democracy" has been the subject of immense attention in (pseudo-) academic literature in the last few decades. The term democracy worked like a magnet, drawing political scientists, philosophers and historians alike to discuss a wide range of aspects associated with it. The immense variety of recent publications that include the word democracy in their titles may be related to the waning of socialism in Eastern Europe and the former Soviet Union, which contributed to the popularity of the term (in a moralising respect, as well as indicating a successful value for serving national interests) among political leaders and commentators in the West. Capitalism, this use of the term democracy suggested, served democracy better than socialism and was a normatively superior political system. Consequently, the term democracy became increasingly used as a 'measure' for the quality of different aspects of the politics of a nation, or any larger or smaller aggregation of individuals. And so the term now reigns in large parts of society, where it pops up in a myriad variety of political discussions that have an evaluative component. Not surprisingly, due to its assumed catch-phrase property, any substantial homogeneity in use of the term democracy went out of the window. ${ }^{2}$ The growing popularity of the term democracy in pseudo-political discourse also contrasts with the fact that the most perceptive theorists of the idea recognise major problems with the inner-logic of any notion of democracy as popular self-government in modern society. ${ }^{3}$ And yet, I will argue, it is the case

\footnotetext{
${ }^{1}$ See the contribution to this volume by Bekkers \& Edwards 'Legitimacy and Democracy in Governance Practices: A Conceptual Framework'.

${ }^{2}$ As every reader of this volume can imagine, internet searches on publications including the word democracy in the title result in a wild variety of uses of the term.

${ }^{3}$ Classic expressions of fundamental problems are Kenneth J. Arrow, Social Choice and Individual Values (1963, 2nd ed, New Haven: Yale University Press) and Joseph A. Schumpeter, Capitalism, Socialism and Democracy (1976 [1943], London: Allen and Unwin). More recently John Dunn, Setting the People Free: The Story of Democracy (2005, London: Atlantic Books) and Democracy: The Unfinished Journey, 508 BC
} 
that looking at the flood of titles containing the word and the conflation of perspectives in even more works dealing with democracy can provide a lead in clarifying issues about the relation between democracy and governance. What is required is the right type of distance from the range of outbursts of calls for democracy and freedom at any level of national and international society.

Taking this right sort of distance (without pretending to move towards a true vantage point) to be able to consider democracy and governance in relation to each other also involves moving away from the focus of almost all contemporary political philosophy that inquires about procedures of aggregation, deliberation, etcetera, in order to confront the typical heavily morally laden use of the term democracy. Finding a philosophical way out of the complexities when confronted, for example, with issues of human rights and democracy becomes an impossible task. In contrast, a more observing, open-minded style of doing political philosophy is more at ease with the challenges of popularised debates about political ideas. Surveying the different ways in which one might conceive of notions of democracy, Raymond Geuss distinguishes between concepts of democracy that refer to empirical institutional orders and concepts that refer to an ideal. ${ }^{4}$ In evaluations of the quality of democracy, he discerns an instrumental approach as well as a normative approach, with the latter claiming that democracy is the morally superior way of ordering a society. A third approach bridges the first two by viewing democracy as an epistemological enterprise that coordinates the 'realisation of human autonomy' and the production of 'exogenous goods, such as social stability, peacefulness and welfare'.

In this article, however, history is the source that is adopted for constructing a view of the relation between democracy and governance. Looking at history with an eye on presentday debates, might shed light on issues about the evolution of political paradigms. While tempting, one approach that is avoided here is looking at democracy through the lens of republican political thought throughout the whole of human history. ${ }^{6}$ To obtain a clear understanding of the particular characteristics of alleged democratic movements at various moments in time, one should be able to consider their actual contexts and very diverse

to AD 1993 (ed. John Dunn, 1992, Oxford: Oxford University Press), Raymond Geuss, History and Illusion in Politics (2001, Cambridge: Cambridge University Press), and Ian Shapiro, The State of Democratic Theory (2003, Princeton, NJ: Princeton University Press) and Democracy's Value (ed. Ian Shapiro and Casiano Hacker-Cordón, 1999, Cambridge: Cambridge University Press).

${ }^{4}$ Geuss, History and Illusion in Politics, pp. 111-9.

${ }^{5}$ On these evaluations of democracy, Geuss, History and Illusion in Politics, pp. 119-24; and on Dewey, pp. 124-6.

${ }^{6}$ See the contributions to Martin van Gelderen \& Quentin Skinner (eds.), Republicanism: A Shared European Heritage (2002, 2 vols., Cambridge: Cambridge University Press), which presents a myriad of different ideas about republicanism that taken together are prone to the accusation that they create more confusion than clarification in the history of political thought. 
historical inspirations. Ancient democracy is usually linked to the major reform experiment by Kleisthenes in Athens in 508 BC, which was in fact an opportunistic attempt, inspired by vindictive motives, to save his own interests against defeat by the power of other aristocrats; ${ }^{7}$ the Italian city states of the late middle ages and the renaissance established self-government in the face of papal and feudal power structures that had emerged after the fall of Rome; ${ }^{8}$ English early modern 'republicanism' had its own much contested circumstances and characteristics; ${ }^{9}$ and still later, ideas of 'representative democracy', which were arguably first developed in the course of the French Revolution, are said to have passed through Mill, onwards to their subsequent transformation into the technical discourse of political theory as we know it. ${ }^{10}$ Any meaningful continuity over time between such a variety of movements can only be imposed and confuses rather than illuminates the issue at hand.

The focus of this piece is only on the eighteenth century and even then it is limited purely to making one specific suggestion about how one might view the relation between governance and democracy. Moreover, in considering eighteenth-century political thought, I merely present a small and sketchy impression of discussions involving ideas of democracy in that age. Yet, these restrictions are justified by the advantages of choosing the eighteenth century as a reference point for treating the issue of governance and democracy.

One obvious reason for postponing directly delving into the matter of the compatibility of governance and democracy should be that confronting the two elements of the issue results in an elusive equation. This is the case not only because democracy and governance are two highly uncertainly moving ideas, but also because they tend to move at different levels of inquiry: governance concerns the organisation of power management, while democracy concerns how personal preferences are absorbed by a political order. Although the two may have strong mutual links, governance and democracy relate to different objects. Thus, it may seem that governance begins where democracy ends (and vice versa), which makes assessing the relative impact on developments on one side of the equation on the other a highly elusive matter. Here, as I will explain, the nature of eighteenth-century debate helps to draw the two closer to each other and bring them together into one frame. By

\footnotetext{
${ }^{7}$ See the articles by Cynthia Farrar ('Ancient Greek Political Theory as a Response to Democracy', pp. 1740) and Simon Hornblower ('Creation and Development of Democratic Institutions in Ancient Greece', pp. 1-16) in Dunn, Democracy: The Unfinished Journey.

${ }^{8}$ See the piece by Quentin Skinner ('The Italian City-Republics', pp. 57-70) in Dunn, Democracy: The Unfinished Journey.

${ }^{9}$ English republicanism is a true publishing industry. For just an example, see Wootton ('The Levellers', pp. 71-90) in Dunn, Democracy: The Unfinished Journey. The wide ranging analysis by J.G.A. Pocock, The Machiavellian Movement: Florentine Political Thought and the Atlantic Republican Tradition (2003 [1975], Princeton, N.J: Princeton University Press) has been very influential.

${ }^{10}$ Indeed, the history of modern democratic theory might be seen as starting only in the late nineteenth century (Geuss, History and Illusion in Politics, p. 110).
} 
adopting an eighteenth-century perspective, one considers the process by which government became governance through the lens of international economic competition and asks whether states ever had and have the opportunities to resist this shift. Also, after the fall of the iron curtain, the liberal-democratic state was hailed as the only remaining political structure that was capable of accommodating the challenges of modern market societies in an international context. Yet, an eighteenth-century point of view would have been ideally suited to temper the enthusiasm and point to deeper problems. In general, an eighteenth-century perspective helps one recognise the limits of what liberal-democratic regimes can be expected to do by showing how political thinkers first responded to the emergence of intensified political and economic competition between states.

The purpose of this chapter is to find a proper object, by means of eighteenth-century political thought, for measuring the extent to which governance might be said to erode democracy in the early twenty-first century. Apparently joining some perceptive political thinkers who insisted as early as a few decades ago that the collapse of socialism did not imply that liberal-democracies were optimally geared to meeting the demands of global political and economic competition, ${ }^{11}$ writers now draw attention to the fact that governance, itself seen as a by product of globalised competition, might erode the democratic quality of such states. After surveying the eighteenth-century background to this issue, I conclude that rather than to see governance as likely to negatively affect democracy, it might be argued with considerable force (as well as historical accuracy) that governance should be expected to enhance democracy.

\section{Democracy Left Behind (the status of the idea before 1790)}

Transposing the discussion of democracy back to the eighteenth century forces one to recognise that democracy was a curse word until the very end of the century, when a strand of American republicans attempted to distinguish their own views from other republican ideas and adopted the term democracy. These late eighteenth-century American republicans broke with a tradition, dating back to Plato and Aristotle, of being highly critical of democracy as a concept in political thought. ${ }^{12}$

Previously, it was by no means excessive to judge democracy in such negative terms as Charles I did, in December 1648, just before he was beheaded. Charles declared that the

\footnotetext{
${ }^{11}$ See the 'Conclusion' (pp. 121-137) of John Dunn, Western Political Theory in the Face of the Future (1993, $2^{\text {nd }}$ ed., Cambridge: Cambridge University Press) and Neal Ascherton, '1989 in Eastern Europe, Constitutional Representative Democracy as a 'Return to Normality'?', in Dunn, Democracy: The Unfinished Journey, pp. 221-237.

12 See Farrar, 'Ancient Greek Political Theory as a Response to Democracy’, in Dunn, 'Ancient Greek Political Theory as a Response to Democracy', and Dunn, 'Conclusion', in Dunn, Democracy: the unfinished journey, pp. 239-66.
} 
'liberty and freedom' of the people 'consists in having of government, those laws by which their life and their goods may be most their own; it is not for having a share in government'. In fact, he judged, 'nothing can more obstruct the long hoped peace of this Nation, than the illegal proceedings of them that presume from servants to become masters and labour to bring in democracy'. ${ }^{13}$ Democracy was the mere illusion that conflict between human beings, fuelled by their divisive passions, had been fundamentally resolved. Popular government was only a thin veil that served to hide such natural conflict. This view, a commonplace for centuries, was also put forward when the United Provinces suffered a joint attack from France and England in 1672. A pamphlet that summarised the state of Dutch republican political thought before the turmoil stressed that democracy should not be confused for a possible form of government. The anonymous pamphleteer cited Jean Bodin as his authority and argued that 'the principle of popular government is that each person desires to be the master over his fellows, and no one desires to obey, if not on the condition that he will reign. But this way the people cannot be held under control' ${ }^{14}$ More than a century later, coining the single term 'democracy' was still sufficient to silence those in England who might see any merit in the constitutional debates in the course of the French Revolution. Whereas regicide and the abolition of property laws could be topics for serious discussion, the revolutionaries' spirit of 'democracy' made them totally laughable. ${ }^{15}$

'Democracy', as discussed so far, stood for the unordered anarchic chaos of antiquity that was to be left behind. The political theories of Bodin and Hobbes served to demarcate the unwieldy forces of the multitude from the orders of the state. ${ }^{16}$ In the eighteenth century, however, democracy had gradually come to be dismissed as a possible system for modern states for new reasons. Enlightenment political thought emerged under the condition of increasing international economic competition between states and developed new approaches to principles of order in societies, as well as between nations. Montesquieu's Spirit of the Laws revolutionised political thought by associating principles of society with systems of government and by evaluating them in the context of eighteenth-century European politics. Montesquieu too (like earlier critics of seventeenth-century English tumults) observed that 'it was a fine spectacle last century to watch the helpless efforts of the English to establish democracy among themselves.' In the midst of great turmoil 'the astonished people searched for democracy and could find it nowhere. In the end, after many movements, shocks and jolts,

\footnotetext{
${ }^{13}$ Dunn, Western Political Theory in the Face of the Future, p. 3.

${ }^{14}$ [Pieter de Huybert], Verdediging van de Oude Hollantsche Regeringh, onder een Stadthouder en een Kapiteyn Generael (1672 [1668], Amsterdam: J. v. Someren), pp. 5-6.

${ }^{15}$ As in Sir Mile's, The Author of the Letter to the Duke of Grafton Vindicated from the charges of Democracy (London, 1794). I thank Mark Somos for providing me with this reference.

${ }^{16}$ Dunn, Democracy: The Unfinished Journey, p. 247 hammers in the point.
} 
they were forced to come to rest in just the same form of government as they had earlier proscribed'. ${ }^{17}$ But Montesquieu's ideas were part of a new type of argument.

Montesquieu held that a large commercial state that had to defend its independence by engaging in foreign trade could not be a democracy. In spite of citizens' zest for liberty, there were higher powers, it seemed, that kept a country like England from being ruled as a democracy. Political advisors, lawyers, merchants and a wide range of scholars writing in the eighteenth century tried to come to grips with these powers. They were consciously aware of the rift between antiquity and modern times, which translated into a gap between democracies and commercial states. Montesquieu was at the absolute forefront of those trying to understand the challenges to eighteenth-century governance. He famously argued that since the late seventeenth century, democracy was a suitable form of government only for some unfortunate small nations; people, for instance, who were 'constrained to hide in marshes, on islands, on the shoals, and even among dangerous reefs' ${ }^{18}$ The survival of these communities traditionally hinged on virtues of frugality, moral discipline, restraint and hard labour. Almost in spite of its founding principles, the United Provinces had become a wealthy merchant republic based on these virtues. But the geographical characteristics and the history of this country set this society (like Venice, Florence and other city republics) apart from Europe's large states, for which it could not serve as a model. On this account, which was among the best worked out arguments of a general commonplace, democracies were an anachronism in Europe. Trade republics were exceptional societies, exemplifying ancient forms of ascetic virtue that were alien to the stuff that modern states thrived on.

Such modern states, which Montesquieu called 'monarchies', were market societies in which the ruling principles were not virtue and love of country, but honour and pride. Individuals interacted through their self-interest, love of money, and their lust for luxury. Inequality was the driving force that enabled states to cultivate their economy and protect their national interest, also through the finance of defensive wars, in a global struggle for hegemony. Containing the excesses of people's self-interested behaviour required the centralised power of a monarchical system. For this reason, market societies simply could not be democracies.

If Montesquieu seems deeply aware of the harshness of eighteenth-century political reality to us, this was not what his contemporaries felt. Some of them believed that Montesquieu had been too positive about the democratic element in monarchies and felt that

\footnotetext{
${ }^{17}$ Montesquieu, The spirit of the Laws (transl. and ed. by A.M. Cohler, B.C. Miller \& H.S. Stone, 1989, Cambridge: Cambridge University Press), Bk. III, Ch. 3, quoted by Dunn, Western Political Theory in the Face of the Future, p. 8.

${ }^{18}$ Montesquieu, The Spirit of the Laws, p. 341.
} 
he displayed too much of a love of democracy. ${ }^{19}$ Yet, on the other side of the debate, even the fiercest critics of commercial competition between states (anti-globalists avant la lettre, as they might be seen) agreed that returning power to the people was not the solution. Reform, they argued, ought not to take place (merely) at the level of the state, but at the level of human nature's capacities for understanding their own true happiness. Getting rid of the threat of economic competition between states spiraling off into all-out global warfare, such as happened in the Seven Years' War of 1756-63, required reforming the corrupt selfish manners of individuals in market societies.

Forty years before Montesquieu distinguished between the tyrannical, democratic and monarchical forms of government, the Neapolitan Paolo Mattia Doria put forward a different division, where he echoed the earlier tripartite division by the French archbishop Fénelon, the archfather of anti-commercial enlightened cosmopolitanism. Doria discussed how market interaction contributed to man's virtue and happiness in three types of political societies. ${ }^{20}$ He distinguished between 'the purely military one, when a people unites itself under a captain, [second] the civil economic one, [...] when one unites under the civil law, but with a frugal and moderate lifestyle, and [third] the civil pompous], which is when one lives in a more cultured and pompous manner. ${ }^{21}$ The second type of society served the public good and functioned in accordance with the essence of human nature. Yet, in the history of humankind, the first type of society had developed into the third. This was due to the invention of money. It was true that money existed in 'all civil and cultured countries' and increased the efficiency of the structures by which people took care of each other's selfpreservation. But money had arisen 'by an ingenious artifice' and as a 'sign' of 'imaginary value'. The invention of money marked the beginning of an 'abstract economy', which was altogether different from the earlier 'natural economy' that existed between people until that point in time. ${ }^{22}$ Money changed people's ideas of their happiness: 'because of the growth of wealth in cities, and by conquests and commerce, people's ideas extend themselves; from simple conveniences they move on to splendour.' Thus injected with fresh divisive energy,

\footnotetext{
${ }^{19}$ For instance, Ferdinando Galiani, Della moneta (1963, ed. A. Caracciolo, Milan: Feltrinelli [1780, $2^{\text {nd }}$ ed., Naples: Raimondi]), pp. 342-3, who judged that Montesquieu had made too much of an attempt to represent monarchies as potentially democratic, which made it seem as though democratic monarchy was within reach, whereby Montesquieu himself caused the imminent Revolution. For Montesquieu's alleged democratic sympathies, see also Nannerl O. Keohane, 'Virtuous Republics and Glorious Monarchies: Two Models in Montesquieu's Political Thought', Political Studies, XX, 4 (1972), pp. 383-96, and Judith Shklar, 'Montesquieu and the New Republicanism', in Machiavelli and Republicanism (eds. Gisela Bock, Quentin Skinner, Maurizio Viroli, 1990, Cambridge: Cambridge University Press).

${ }^{20}$ Paolo Matta Doria, La Vita Civile (1710, $2^{\text {nd }}$ edition, Naples), pp. 319-337, discusses the nature of markets; pp. 117-29 give the outlines of Doria's three types of political societies.

${ }^{21}$ Doria, La Vita Civile, p. 116.

${ }^{22}$ Doria, La Vita Civile, pp. 321-22.
} 
reciprocal exchange turned into competition and human history spiraled off into increasing jealousy between individuals and states.

Doria accepted that the clock could not be turned back and argued that monarchies were a better form of government than democracies for containing the consequences of the introduction of money. Democracies required 'virtues that were more true than monarchical states' and were 'more vulnerable to turbulences and revolts when the virtue of the citizens corrupted and degenerated into vicious ambition.' Instead, a wise king would be able to steer the development of those sectors of the economy that were directly related to the satisfaction of people's basic needs, and abstain from engaging in luxury trade and balance of trade politics. $^{23}$

In this way, early eighteenth-century cultural critics did not advocate the return of political power to the people, but instead devised ways of taking their vices away from them. Their reform proposals did not attempt to let the multitude back in, but rather set out to unite a divided mankind.

\section{Commerce, Competition and International Governance: Continuities in the Modern}

\section{World}

If the central concern of present-day political debate across the board involves the term democracy (or the democratic quality of society), the connecting themes in eighteenth-century political discourse were commerce and morality. From attitudes towards the reform of nations into viable commercial societies to the level of global governance, this theme dominated Enlightenment politics. It might also be argued that Enlightenment ideas about commerce and morality are, in some sense, the equivalent of ideas about 'democracy' now. To see the grounds for comparison, we need to look beyond the fact that democracy was neither on the cards as a possibility, nor as a desire for improving the well-being and quality of people in

\footnotetext{
${ }^{23}$ It is often claimed that Doria's distinction between different types of government by their principles and his discussion of true and false virtue were an influence on Montesquieu's De l'esprit des lois, but it should at least be recognised that Doria's message was rather the opposite of Montesquieu's. Montesquieu's concept of the moral foundations of modern commerce was diametrically opposed to Doria's. Whereas Doria saw money and luxury themselves as a danger, Montesquieu believed that they lay at the roots of the increased happiness of modern societies compared with earlier ones. Montesquieu's message was expressed very clearly in the Persian letters, through a critique on Fénelon's reform proposals in the form of a parody on Fénelon's Boetica and the reform of Salentum. Doria's critique of the aristocracy was typical and rehearsed the accusations towards the nobility's expensive fashions, spendthrift and obstructions of the interest of the people. It preceded the critical reception of Montesquieu's De l'esprit des lois in Naples (see E. De Mas, Montesquieu, Genovesi e la edizione del spirito delle leggi (Florence: Olschki, 1971). In that sense certainly, Doria's analysis of the sources of moral corruption and its political consequences is more accurately seen as a proto-Rousseauian cultural critique of modern society. It is also possible that Rousseau knew Doria’s La vita civile. Jean LeClerc's review in 1716 commented on Doria's way of turning his rejection of luxury into an argument that demanded its correction through a system of political absolutism.
} 
civil society. In this way, it becomes possible to recognise that early eighteenth-century politics still revolved around much the same issues as early twenty-first century politics.

In the mid eighteenth century, national states faced large economic pressures resulting from international competition for hegemony between states. In order to protect the preservation of power and wealth in this international context, smaller states sought to align their national interest with alternative forms of international governance. The problem was commercial competition. As Giovanni Francesco Pagnini noted in his introduction to the Italian translation of John Locke's writings on money, published in 1751 in Florence, commerce decisively divided humankind, even in times of peace. The importance of trade as an aspect of the political survival of states had created a world in which governments were 'obliged to compete with others for the society of commerce, in order to attain their own conservation, their wealth and power'. Whereas strategy used to be crucial in warfare, Pagnini argued, now 'one watches with the same eyes at those citizens who by means of arts and manufactures, no less than soldiers, contribute to' the conservation of the state. ${ }^{24}$

In his introduction to Locke's monetary writings, Pagnini stressed the ambivalent consequences of the caesura between antiquity and modernity. Pagnini keenly repeated Montesquieu's dictum that 'the Romans never knew jealousy of trade. They attacked Carthage as a rival nation, instead of as a commercial nation' ${ }^{25}$ Pagnini's remarks were made against Pompeo Neri, a prominent lawyer and government official from Tuscany, who became famous for his role in the census reform in Lombardy in the years after 1750. Neri, had published a work on monetary reform, entitled Osservazioni sopra il prezzo legale delle monete (1751), in which he argued that in a modern 'commercial nation, everyone who did not live in solitude' had 'his interest linked to foreigners'. The natural 'universal commerce of mankind' united 'the whole society of mankind' into 'one single universal republic'. ${ }^{26}$ Commerce connected people all over the world in a universal society that had precedence over political societies. Thus, according to Neri, commerce always retained its own supranational character and was immune for any political manipulations.

Neri's Osservazioni formed a crucial statement from Milan in the context of a series of negotiations with the court of Turin to form a monetary union with Lombardy and Tuscany. ${ }^{27}$ Pagnini himself was a government minister in the grand duchy of Tuscany, who was responsible for financial administration and thus on the receiving end of Neri's proposals

\footnotetext{
${ }^{24}$ See John Locke, Ragionamenti sopra la moneta, l'interesse del danaro, le finanze e il commercio, (Vol. I, Florence, 1751), pp. 96-8; see also K. Stapelbroek, 'The devaluation controversy in eighteenth-century Italy', History of Economic Ideas (2005), 13 (2), pp. 79-110.

${ }^{25}$ Locke, Ragionamenti sopra la moneta, pp. 223-64.

${ }^{26}$ Pompeo Neri, Osservazioni sopra il prezzo legale delle monete (Milan, 1751), pp. 40, 121.

${ }^{27}$ Franco Venturi, 'Il dibattito sulle monete', Da Muratori a Beccaria (Settecento riformatore, vol. I, Turin, 1969), pp. 468-77.
} 
for an Italian monetary union. Like Neri, Pagnini described 'commercial society' as 'a type of society' that created 'universal' ties between people and which was 'supereminente' - it transcended all categories of political power. This type of society emerged when, in the course of history, the 'needs and desires of people' expanded, and more people - as well as more complicated organisational structures - were necessary to satisfy them. Yet, Pagnini stressed, this 'new sort of society [that] was formed between people far away from each other' united people who were also, and already, divided 'by the universal of their relations in various different bodies and societies'. ${ }^{28}$ Commerce united people, but states divided them. Thus Pagnini's message to Neri was that commerce did not actually unite humankind into a single republic. Pagnini agreed with Neri that people's interests were linked through trade, but felt that Neri had been mistaken about the moral foundations as well as the political consequences of commercial society and that this affected the realism of his design of a monetary union. When Pagnini - a Florentine government minister responsible for financial affairs - wrote about Locke and antiquity, the message to Neri (who had also used Locke's ideas in support of his monetary union) was that Tuscan officials held different ideas of the nature of commerce and were not going to support Neri's plan for a monetary union.

Pagnini's response to Neri brings to light a confrontation between two of the most influential European perspectives on international governance in the eighteenth century. These rival views were built on alternative conceptualisations of the nature of market exchange relationships and their political correlates and consequences. Was commerce capable of channeling the most violent passions for domination in human nature or would it amplify them and turn trade into a new object of aggressive competition between states? Neri was optimistic and thought that a monetary union that served to regulate international trade was naturally in every state's interest. Pagnini thought this was naïve but still believed that the aggressive excesses of commercial competition between states would check themselves since the economic costs of warfare would be too high to make belligerent powers emerge as winners in the modern world.

The Italian debate on money and its regulation in an international context was only one slice of the European Enlightenment. The general challenge of the latter was to find moral and political standards for making separate national interests correspond to a global order in which trade competition was monitored and threats to peace were neutralised. With these ideals in mind, eighteenth-century political thinkers reflected on a series of institutional reform arrangements and contemplated large-scale financial experiments involving the national debt. Thus progressing, the term democracy used in a positive sense, quite surprisingly, resurfaced near the end of the eighteenth century.

\footnotetext{
${ }^{28}$ Locke, Ragionamenti sopra la moneta, pp. 160-3.
} 


\section{The Invention of Modern Democracy in the 1790s}

The enduring pressure of international competitive forces on national states and their policy strategies in the eighteenth century triggered a momentous international exchange of ideas about human nature, self-interest and morality, which is usually referred to as the Enlightenment. The formulation of these ideas, as we saw, went along with reflections on projects for aligning domestic policies with character of international governance. Likewise, the imperative logic of commerce and competition forced French thinkers and, under different conditions, the American founding fathers to reconsider principles of government and mechanisms of aggregation of individual interests into state interest. From these contexts of eighteenth-century policy, redevelopment processes ensued what has become our present-day positive use of the term democracy.

It is necessary to consider two interdependent genealogies of the notion of democracy in the modern world. One involves French Enlightenment political thought, from anti-Louis XIV sentiments in the first decades of the century to the constitutional debates in the aftermath of the French Revolution. The expensive wars of the time of Louis XIV that immersed the nation in debt lay at the root of a century of thinking about reforms. Coming to terms with the lasting consequences of Louis XIV's reign for France's place in Europe and laying out a plan for its economic and political future, the heavily polarised debate oscillated between the two ideological poles of neo-Colbertist 'mercantilism' and Fénelonian moralising cosmopolitan agriculturalism. In order to get rid of the burden of public debt and mitigate the effects of dynastic rule, a series of spectacularly daring attempts to revive the French economy and to prevent the Revolution were proposed. Gradually, the opposed positions moved closer to each other in the course of the century, and mutually adopted elements of the other party's solutions. ${ }^{29}$ At the end of process stood the political works and constitutional proposals of the abbé Emmanuel Sièyes. ${ }^{30}$

Sièyes himself did not so much reintroduce the term democracy into political thought as create the preconditions for it to become a label of the type of state structure that he envisaged as the solution for grounding the finances of the French state upon new constitutional principles. Sièyes became known, not undeservedly, as the main inventor of what is now called representative democracy. In the advent of the Terror following the French

\footnotetext{
${ }^{29}$ See M. Sonenscher, 'The Nation's Debt and the Birth of the Modern Republic: The French Fiscal Deficit and the Politics of the Revolution of 1789', History of Political Thought, 18[1-2] (1997), 64-103, 267-325, for the relation between the public debt in France and the French Revolution as an option for reform in the decades before 1789 .

${ }^{30}$ See Michael Sonenscher, ed., Sieyès: Political Writings, Including the Debate between Sieyès and Tom Paine in 1791 (Indianapolis, Ind.: Hackett, 2003).
} 
Revolution, he was one of the main architects of the system in which the new republic, led by a commercial bourgeois class, took over the public debt of the French royal state and put itself at the head of a market society. For Sièyes it was clear that the type of constitution he invented was not a democracy, but rather its opposite. In the first place, representative government did not give the power to rule back to the people, but responded to a more pressing and altogether different need: 'The common interest, the improvement of the state of society itself cries out for us to make Government a special profession'. ${ }^{31}$ Sièyes' structures formed mainly a solution for the problem of canceling the national debt and created a buffer against political power abuse through dynastic ambitions that were alien to the national interest. The new French state should simply be led by people who could be expected to act more naturally in its economic and political interest. This system of government that arose out of the French Revolution entailed some idea about the moral accommodation of selfinterested market behaviour, but did not necessarily aim principally to sort out any problems of inequality, injustices and inefficiencies of commercial society. It certainly did not abandon the idea that commerce was a primarily selfish activity, in local markets, as well as internationally. Sièyes' state was too firmly grounded in a Hobbesian social psychology to be confused for a cosmopolitan theory of universally united free democracies. ${ }^{32}$

In the same period, the American constitutional debate revolved around similar issues. One of its icons, Thomas Paine, suggested that representative democracy was in fact quite close to democracy, only better. The American state was 'representation ingrafted upon Democracy'. While direct democracies were 'inconvenient', nothing was lost, and a lot of efficiency was added in representative democracies. Thus, Paine denied what was initially implicit and increasingly explicit in Sieyes' writings, that democracy was a misnomer for representative government. For Paine, representative government was fortified direct democracy.

Moreover, Paine imagined that representative democracies were the most suitable structures for realising the potential of commerce for transforming competing states into a universal republic of humankind. Paine held that commerce was 'a pacific system, operating to cordialise mankind, by rendering Nations, as well as individuals, useful to each other'.

\footnotetext{
31 Quoted by Bernard Manin, The Principles of Representative Government (Cambridge: Cambridge University Press, 1997), p. 3. In his introduction, Manin stresses that Sièyes (and Madison) opposed direct democracy.

${ }^{32}$ Istvan Hont, 'The Permanent Crisis of a Divided Mankind. 'Contemporary Crisis of the Nation State' in Historical Perspective’, in: Political Studies (ed. John Dunn, 1994), pp. 166-231, reprinted in Jealousy of Trade: International Competition and the Nation-State in Historical Perspective (Cambridge, MA: Belknap Press of Harvard University Press, 2005), of which see pp. 125-141.
} 
Commerce was set to bring about a 'universal civilization' and representative democracy was the state form that would make this vision come true. ${ }^{33}$

Unsurprisingly, in 1792 Paine was the first person in modern times to mention the term democracy in a positive way, in the second part of the Rights of Man. ${ }^{34}$ Edmund Burke responded to Paine by accusing him of not having the faintest idea what democracy was, that democracy was put of place in modern times, and that it was ultimately naïve to believe that some idea of it might be useful in late eighteenth-century politics. ${ }^{35}$ In spite of Burke's immediate critique, and of a host of similar complaints expressed in the form of pamphlets, Paine's idea to call representative government democracy caught on in the American republican constitutional debates of the time. Andrew Jackson's hired pens popularised the idea further by exploiting its imaginative appeal, and the idea of democracy was given a new lease.

The differences between Sièyes and Paine were played out against each other directly in correspondence with each other (and about each other to other people). Obviously, Sièyes disliked Paine's use of the term democracy, which made representative government look like something it was not. More importantly, he could not agree with Paine's views that made it seem as though what he called democracy was capable of radically changing the face of the earth. Paine's democracy promised far too much.

A mediocre parody on Paine's Rights of Man, II exemplifies the standard reaction among contemporaries to his idealistic image of the role of the American style of government in a global trend towards peaceful universal commerce. The anonymous author of Buff, or $a$ dissertation on nakedness, a parody on Paine's Rights of Man (London, 1792) interpolated a number of phrases, replacing ideas of freedom with ideas of nakedness, thereby transforming 'the grand chorus of the Rights of man' into 'a canzonetta on Nakedness'. The text of Buff included Paine's original critique of Sièyes' alleged hesitation to present his democratic sentiments in the form of a democratic theory:

The preference which the Abbé has given is a condemnation of the thing he prefers. Such a mode of reasoning is inadmissible, because it finally amounts to an accusation upon Providence as if she had left to man no other choice than between two evils, the best of which he admits to be an outrage upon society. This sort of superstition may last a few years more, but it cannot long resist the awakened reason and interest of man. ${ }^{36}$

\footnotetext{
${ }^{33}$ Thomas Paine, Political writings (ed. by Bruce Kuklick, Cambridge: Cambridge University Press, 2000).

${ }^{34}$ Thanks to Mark Somos who went through a great many sources of the time to establish this significant fact. See Paine, Political writings, pp. 229-31. The idea was repeated in Paine's Dissertations on the first principles of Government, of 1795.

${ }^{35}$ For the context of the French and American debates revolving around Paine and Burke see Gregory Claeys (ed.), Political Writings of the 1790s (London, Pickering \& Chatto, 1995), esp. vols. I-II, V-VI.

${ }^{36}$ [Anonymous], Buff, or a Dissertation on Nakedness, a Parody on Paine's Rights of Man (London, 1792), p. 15.
} 
In the hands of Paine, Sièyes's views had been seriously disfigured. Paine associated Sièyes political vision with his own ideal of a providentially guided evolution of global politics towards cosmopolitan democracy. This allowed the author of Buff, for instance, to suggest that both thinkers advocated a return to primitive nature, and to confuse Sièyes's idea of commercial freedom in a state for pre-social nakedness. Whereas Sièyes' constitutional proposals had a clear limited purpose and remained strictly within the boundaries of a particular eighteenth-century political debate, Paine's promises for the future of democracy seemed designed to virtually overturn the whole of human history. Paine’s use of democracy not only provoked critics to revert to classical disqualifications of democracy as uncivilised anarchic lack of order, it also inadvertently invited confusion about the focus and limits of modern politics.

\section{Conclusion: Expectations from and Limits of Modern Democracy}

In present-day western (and global) politics, representative democracy is the dominant system of government. But what can be expected of it? An excursus into the eighteenth-century history of the term democracy has brought up two interpretations of what representative democracy might be taken to stand for and what citizens of a particular state might reasonably understand to be the purpose of this form of government.

It would be most in tune with Sièyes's eighteenth-century perception to see modern democracy (deceptively) simply as the name of a system of representative government that charges politicians with the responsibility of taking care of the interest of the nation. In the words of John Dunn, the strength of such a system of government resides in its fragility. It preserves its integrity as a counteracting force to democracy and smoothes the sharp edges of capitalism, and for these reasons it has proven resilient in the modern world. ${ }^{37}$ In this perspective, the purpose of the state is not seen as understanding and regulating markets and their moral functioning. Insofar as politics interferes with the outcomes of market interaction, this is based on the notion that the security of individuals is to be protected, not necessarily on theoretical principles of social justice. Similarly, the balance between private and public goods is based on continuous negotiation between actors in the public realm, rather than on an externally imagined, or defined, standard of where the responsibility of the state ceases. Representative democracy, thus understood, is an essentially open-ended, and undefined style of government. One of its strengths, it appears, has been its implicit acceptance of the limits of thinking about the relation between commerce and politics (or capitalism and democracy). ${ }^{38}$ Whereas Paine held ambitious ideals in which nations might be united through

\footnotetext{
${ }^{37}$ Dunn, Democracy: The Unfinished Journey, pp. 246-52, 258.

${ }^{38}$ Dunn, Democracy: The Unfinished Journey, pp. 252-5, 259-60, 263.
} 
commerce, Sièyes's mechanisms of representative government were not based on any particularly fixed idea of markets as playing a role in bridging gaps between states. Consequently, Sièyes's views could not lead to anywhere near the wild promises about the power of democracy that Paine made and that seem much closer to the present-day discourse of democratic government in which democracy eventually became 'the name for the good intentions of states or perhaps for the good intentions which their rulers would like us to believe that they possess' ${ }^{39}$

As signaled in the first section, in recent decades the use of the term democracy widened, through which it became a label for various reference points by which politicians, commentators in the media and other writers juxtaposed desirable and reprehensible aspects of their own and other societies. Democracy in an international context is often seen as the opposite of tyranny by the state (and lack of a political system in which elections have a place apparently makes such states illegitimate). ${ }^{40}$ Similarly, the idea of a democratic deficit in modern western states (liberal democracies) represents a host of similar complaints, though very moderate versions of real struggles against tyranny: people feel their liberties could be better taken care off, the exercise of their activities is curbed, the desires that people see as part of their identities are somehow interfered with. Democracy can mean the absence of imperfections in how individuals in a nation-state feel about the organisation of their societies and the arrangement of political prerogatives. But one also considers, for instance, the future of Islam in the western world as the question whether Shariya law is reconcilable with democracy. The most convincing argument for winning over popular opinion in western nations to justify intervening in the affairs of a sovereign state is that democracy has to be installed. And, interestingly an important perspective on how violence against western societies might be countered led to a book entitled Terrorism Versus Democracy (which was first published before 9/11, but unsurprisingly has had a lot of reprints). ${ }^{41}$

Such widespread use of the term democracy in evaluating the state of affairs in disparate fields of society stands in shrill contrast to the serious limitations that contemporary political thinkers perceive in theories of democracy. ${ }^{42}$ The real problem does not seem to be that representative democracy is incapable of furthering people's well-being. But there appears to be a genuine gap between the way in which it does so, and the manner in which party politics in the western world suggests more ambitious purposes for representative

\footnotetext{
${ }^{39}$ Dunn, Western Political Theory in the Face of the Future, p. 13.

${ }^{40}$ The Second World War Allies, according to John Dunn (Setting the People Free, the Story of Democracy), converted 'democracy' into a slogan, in a manner not too dissimilar to how Tom Paine's use of the term turned it into a slogan in the American 1790s.

${ }^{41}$ Paul Wilkinson, Terrorism Versus Democracy: The Liberal State Response (London: Cass, 2001).

${ }^{42}$ See Shapiro, The State of Democratic Theory and Democracy's Value, and Geuss, History and Illusion in Politics.
} 
democracy than are feasible. Insofar as democratically elected politicians set out to remove abuses of power and protect the security and facilitate the interested action of individual citizens, they act in accordance with Sièyes's purpose of representative democracy. But when politicians promise and subsequently, after being elected, are expected to create public happiness, the limits of representative democracy are exposed. The confusion about the limits of modern democracy that arose from the Sièyes-Paine controversy has a prominent place at various levels of present-day politics. While politicians simply do their job, but promise to do more than that, people expect ever more from democratic governments.

To conclude, nowadays - in everyday language, news programmes in the media, as well as in academic publications - the term democracy is predominantly used as a shorthand indicating simultaneously a type of political system and its presumed objective. That is to say, since the second half of the twentieth century, the word democracy increasingly represents an imagined touchstone of desirable political organisation, in which the liberties and maximum happiness of the people are guaranteed. As such, it is often associated with the notion of representative government and the constitutional arrangements that were proposed by the abbé Emmanuel Joseph Sieyès in the French Revolution. However, as we have seen, representative democracy, understood as the careful transferal of sovereignty to the nation without abandoning the absolute rule of the state, was at the time specifically proposed as a possible antidote to the escalation, at home and abroad, of economic competition between states. This idea of representative democracy is to be seen as the result of eighteenth-century political thought. Yet, in the course of the last centuries, the word democracy has come to bear other connotations. The term democracy, in its current meaning, effectively implies the success of a specific political order in silencing potential disorders arising from natural and artificial characteristics of communities of people. If this use of the term is taken to be the outcome not of a wild semantic drift, but of a proper development of the idea of democracy caused by a particular logic of historical complexity, how might the idea of governance fit in?

What is called lack of democracy is not the failing of but rather the imperfections of representative government. Representative democracy emerged as a way of correcting domestic styles of governance with an eye on international commercial competition, but it is now expected to perfect national politics. One might explain the perceived shift from government to governance through this context. Could it be the case that the rise of governance, as distinct from centralised state government, is a response (in whatever way) to the gap between authentic purposes of representative government and the promises and expectations that go along with present-day meanings of the word democracy? Thus, governance would be seen as supplementing representative government and forcing Hobbesian states to give way, in a controlled manner, to the forces of the multitude. If this is 
the case, it would seem more reasonable to wonder whether governance has not increased democracy in modern societies, instead of whether it sustains and enhances a democratic deficit in the modern world. Any positive answers would suggest a historical turning point since democracy, really, was never a realistic notion in modern politics. But for any statement on the issues goes that in order to be instructive, it is crucial to first eliminate basic confusions about the term democracy and its history.

\section{References:}

[Anonymous], Buff, or a Dissertation on Nakedness, a Parody on Paine's Rights of Man (London, 1792).

Arrow, Kenneth J., Social Choice and Individual Values (1963, 2nd ed, New Haven: Yale University Press).

Claeys, Gregory (ed.), Political Writings of the 1790s (8 vols. London, Pickering \& Chatto, 1995).

De Mas, Enrico, Montesquieu, Genovesi e la edizione del spirito delle leggi (Florence: Olschki, 1971).

Doria, Paolo Mattia, La Vita Civile (1710, $2^{\text {nd }}$ edition, Naples),

Dunn, John, Setting the People Free: The Story of Democracy (2005, London: Atlantic Books).

Western Political Theory in the Face of the Future (1993, $2^{\text {nd }}$ ed., Cambridge: Cambridge University Press).

Democracy: The Unfinished Journey, 508 BC to AD 1993 (ed. John Dunn, 1992, Oxford: Oxford University Press).

Galiani, Ferdinando, Della moneta (1963, ed. A. Caracciolo, Milan: Feltrinelli [1780, $2^{\text {nd }}$ ed., Naples: Raimondi]),

Gelderen, Martin van \& Q.R.D. Skinner (eds.), Republicanism: A Shared European Heritage (2002, 2 vols., Cambridge: Cambridge University Press).

Geuss, Raymond, History and Illusion in Politics (2001, Cambridge: Cambridge University Press).

Hont, István, Jealousy of Trade: International Competition and the Nation-State in Historical Perspective (Cambridge, MA: Belknap Press of Harvard University Press, 2005).

'The Permanent Crisis of a Divided Mankind. 'Contemporary Crisis of the Nation State' in Historical Perspective', in: Political Studies (ed. John Dunn, 1994).

[Huybert, Pieter de], Verdediging van de Oude Hollantsche Regeringh, onder een Stadthouder en een Kapiteyn Generael (1672 [1668], Amsterdam: J. v. Someren).

Keohane, Nannerl O., 'Virtuous Republics and Glorious Monarchies: Two Models in Montesquieu's Political Thought', Political Studies, XX, 4 (1972), 383-96.

Locke, John, Ragionamenti sopra la moneta, l'interesse del danaro, le finanze e il commercio, (II vols., Florence, 1751).

Manin, Bernard, The Principles of Representative Government (Cambridge: Cambridge University Press, 1997). 
Mile, Sir , The Author of the Letter to the Duke of Grafton Vindicated from the Charges of Democracy (London, 1794).

Montesquieu, The Spirit of the Laws (transl. and ed. by A.M. Cohler, B.C. Miller \& H.S. Stone, 1989, Cambridge: Cambridge University Press).

Neri, Pompeo, Osservazioni sopra il prezzo legale delle monete (Milan, 1751).

Paine, Thomas, Political Writings (ed. by Bruce Kuklick, Cambridge: Cambridge University Press, 2000).

Pocock, J.G.A., The Machiavellian Movement: Florentine Political Thought and the Atlantic Republican Tradition (2003 [1975], Princeton, N.J: Princeton University Press).

Schumpeter, Joseph A., Capitalism, Socialism and Democracy (1976 [1943], London: Allen and Unwin).

Shapiro, Ian, The State of Democratic Theory (2003, Princeton, NJ: Princeton University Press).

Democracy's Value (eds. Ian Shapiro \& Casiano Hacker-Cordón, 1999, Cambridge: Cambridge University Press).

Shklar, Judith, 'Montesquieu and the New Republicanism', in Machiavelli and Republicanism (eds. Gisela Bock, Quentin Skinner, Maurizio Viroli, 1990, Cambridge: Cambridge University Press).

Sonenscher, Michael (ed.), Sieyès: Political Writings, Including the Debate between Sieyès and Tom Paine in 1791 (Indianapolis, Ind.: Hackett, 2003).

'The Nation's Debt and the Birth of the Modern Republic: The French Fiscal Deficit and the Politics of the Revolution of 1789', History of Political Thought, 18 [1-2] (1997), 64-103, 267-325.

Stapelbroek, Koen, 'The Devaluation Controversy in Eighteenth-Century Italy', History of Economic Ideas (2005), 13 (2), 79-110.

Venturi, Franco, 'Il dibattito sulle monete', Da Muratori a Beccaria (Settecento riformatore, vol. I, Turin, 1969), pp. 468-77.

Wilkinson, Paul, Terrorism Versus Democracy: The Liberal State Response (London: Cass, 2001). 